\title{
PEMPHIGUS DIAGNOSTIKOS IR GYDYMO AKTUALIJOS
}

\author{
Justė Kantauskaitė, Jurgina Ūselienė, Irena Marčiukaitienė, Jūratė Grigaitienė \\ Vilniaus universiteto ligoninès Santaros klinikos, Dermatovenerologijos centras, \\ Vilniaus universiteto Medicinos fakultetas
}

Raktažodžiai: pūslinè (pemphigus), desmogleinai, autoantikūnai, imunofluorescencija, desmokolinas, desmoplakinas, envoplakinas, periplakinas, plektinas, odos stulpelinè biopsija, sisteminiai imunosupresantai, plazmaferezè, imunoadsorbcija, rituksimabas, intraveninis imunoglobulinas.

\section{Santrauka}

Pūslinè (pemphigus) - heterogeniška autoimuninè odos ir gleivinių liga, susijusi su IgG ir IgA autoantikūnų gamyba prieš skirtingas adhezijos molekules epidermyje ir pasireiškianti intraepiderminemis pūslèmis, kurios dèl plono paviršiaus greitai plyšta. Pemphigus klasifikuojama ị keletą nozologinių vienetų, kurie tarpusavyje skiriasi patogeneze, autoantikūnų prisijungimo vieta odoje, bėrimo pobūdžiu bei lokalizacija. Dažniausia iš jų - paprastoji pūslinè, 70 proc. atvejų prasideda burnos gleivinejje, odoje stebimos skausmingos, sunkiai gyjančios erozijos. Lakštinè pūslinė dažniausiai pažeidžia tik odą, jai būdingos erozijos, padengtos hiperkeratotine pleiskana. Paraneoplastinè pūslinè - daugiažidininio autoimuninio paraneoplastinio sindromo pasireiškimas odoje ir gleivinèse, labai heterogeniškais klinikiniais simptomais. Vaistų sukelta pemphigus išgydoma ekskliudavus ją sukèlusị vaistą. Šių ligų diagnostika pagrịsta anamneze, klinikiniu ištyrimu, laboratoriniais tyrimais. Iš jų svarbiausias - tiesioginè imunofluorescencija, kuri pasaulyje yra „auksinis“ standartas pemphigus nustatyti diagnozę. Pemphigus gydymas - sudetingas ir ilgalaikis, priklausantis nuo patogenetinio mechanizmo ir ligos klinikinès išraiškos, todèl prieš sudarant gydymo planą reikia kruopščiai ịvertinti paciento būklę. Pūslinio pažeidimo ir funkcinio sutrikimo, susijusio su liga, gydymas, ligos atsinaujinimo kontrolè, dažniausių šalutinių reiškinių, susijusių su ilgalaikiu gydymu kortikosteroidais ir imunosupresantais sumažinimas, paciento gyvenimo kokybès gerinimas yra pagrindiniai tikslai diagnozavus šią ligą. Pirmo pasirinkimo vaistais gydant pūslinę iki šiol išlieka sisteminiai kortikosteroidai, kuriuos derinant kartu su adjuvantais, klinikinę ligos remisiją galima pasiekti mažiausiomis kortikosteroidų dozèmis.

\section{Ivadas}

Pūslinès (pemphigus) ligų grupè - tai autoimuninès intraepidermalinès pūslinès ligos, pažeidžiančios odą ir/ar gleivines. Pemphigus autoimuninis procesas nulemia pūslių formavimosi vietą, ligos klinikinę išraišką ir eigą bei gydymo taktiką. Šios ligos prognozè iki gydymo eros sisteminiais kortikosteroidais (KS) ir imunosupresiniais vaistais dažniausiai buvo bloga. Gausios akantolizinès pūslès ir išplitusios šlapiuojančios erozijos odoje ir gleivinèse, skysčių ir proteinų netekimas, elektrolitų disbalansas dèl odos barjero pažeidimo, antrinè bakterinè, virusinè ar grybelinè infekcijos buvo letalios baigties priežastys [1,2]. Pemphigus diagnostika sudètinga, dažnai - pavèluota, ypač kai bèrimai prasideda tik burnos gleivineje. Tokiais atvejais pacientai dažniausiai kreipiasi ị odontologus ir tik atsiradus pažeidimams odoje kreipiasi į dermatologus. Diagnozuojant pemphigus, neretai nustatoma klaidingai neigiama tiesioginès imunofluorescencijos mikroskopija, kuri pasaulyje yra „auksinis“ standartas šios ligos diagnostikoje. Tai priklauso nuo biopsijos atlikimo technikos, biopsinès medžiagos transportavimo ir laiku atlikto histopatologinio ịvertinimo [1]. Pemphigus gydymas yra sudetingas ir ilgalaikis, reikalaujantis ilgalaikès gydymo kontrolès, šalutinių reiškinių, sukeltų imunosupresinių vaistų, prevencijos. Paciento gyvenimo kokybės, gretutinių, papildomų sveikatos sutrikimų prevencija priklauso nuo ankstyvos ir tikslios ligos diagnozès, savalaikio šiuolaikinio priešuždegiminio ir imunosupresinio gydymo bei kontrolès. Ankstyva ligos diagnozė ir šiuolaikinis priešuždegiminis ir imunosupresinis gydymas gerokai sumažino pacientų mirtingumą, kuris dabar dažniausiai susijęs su ilgalaikio imunosupresinio gydymo komplikacijomis $[1,3]$.

Šio straipsnio tikslas - pateikti pemphigus diagnostikos, gydymo parinkimo, ilgalaikio gydymo, pacientų stebejjimo ypatumus, kurie iš esmès gali keisti diagnozès nustatymo tikslumą, ligos baigti bei paciento gyvenimo kokybę. 
1 lentelė. Pemphigus klinikinès formos [3, 6, 10, 13, 16-19]

\begin{tabular}{|c|c|}
\hline IGA & KLINIKA \\
\hline 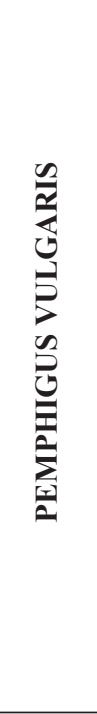 & $\begin{array}{l}\text { Klasikinė PV: } \\
\text { - dažniausia iš pemphigus - } 70 \text { proc.; } \\
\text { - dažniausiai pažeidžiamos vietos: burnos gleivinė, galva, veidas, mechaniškai pažeidžiamos sritys, nagai, odos } \\
\text { raukšlès; } \\
\text { - } 70 \text { proc. prasideda burnos gleivinėje; } \\
\text { - skausmingos, ilgai išliekančios erozijos; } \\
\text { - pūslès lengvai plyšta, todėl dažnai matomos tik erozijos ir šašai; } \\
\text { - niežti retai; } \\
\text { - sunkiais atvejais, esant pažeistiems dideliems plotams - organizmo skysčių netekimo bei antrinės infekcijos } \\
\text { rizika; } \\
\text { - teigiamas tiesioginis ir netiesioginis Nikolsky simptomas. } \\
\text { - Vegetacinė PV: } \\
\text { zinėmis, verukozinėmis vegetacijomis; } \\
\text { - dažniausiai pažeidžiamos vietos: raukšlės, perioralinė zona, kaklas, galva; } \\
\text { - klinikinės formos: } \\
\text { - Neumann tipas: agresyvus paprastosios pūslinės tipas, kuriuo sergant ilgainiui atsiranda baltos maceruotos plokštelės; } \\
\text { - Hallopeau tipas (pyodermite vegetante): lengvesnė forma nei Neumann tipas. Prasideda raukšlių srityse pustulėmis, } \\
\text { kurios vėliau virsta į verukozinio tipo bėrimus. }\end{array}$ \\
\hline 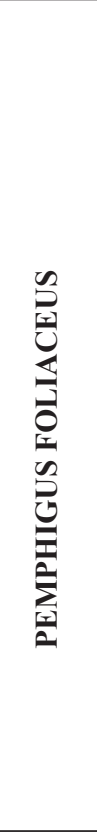 & 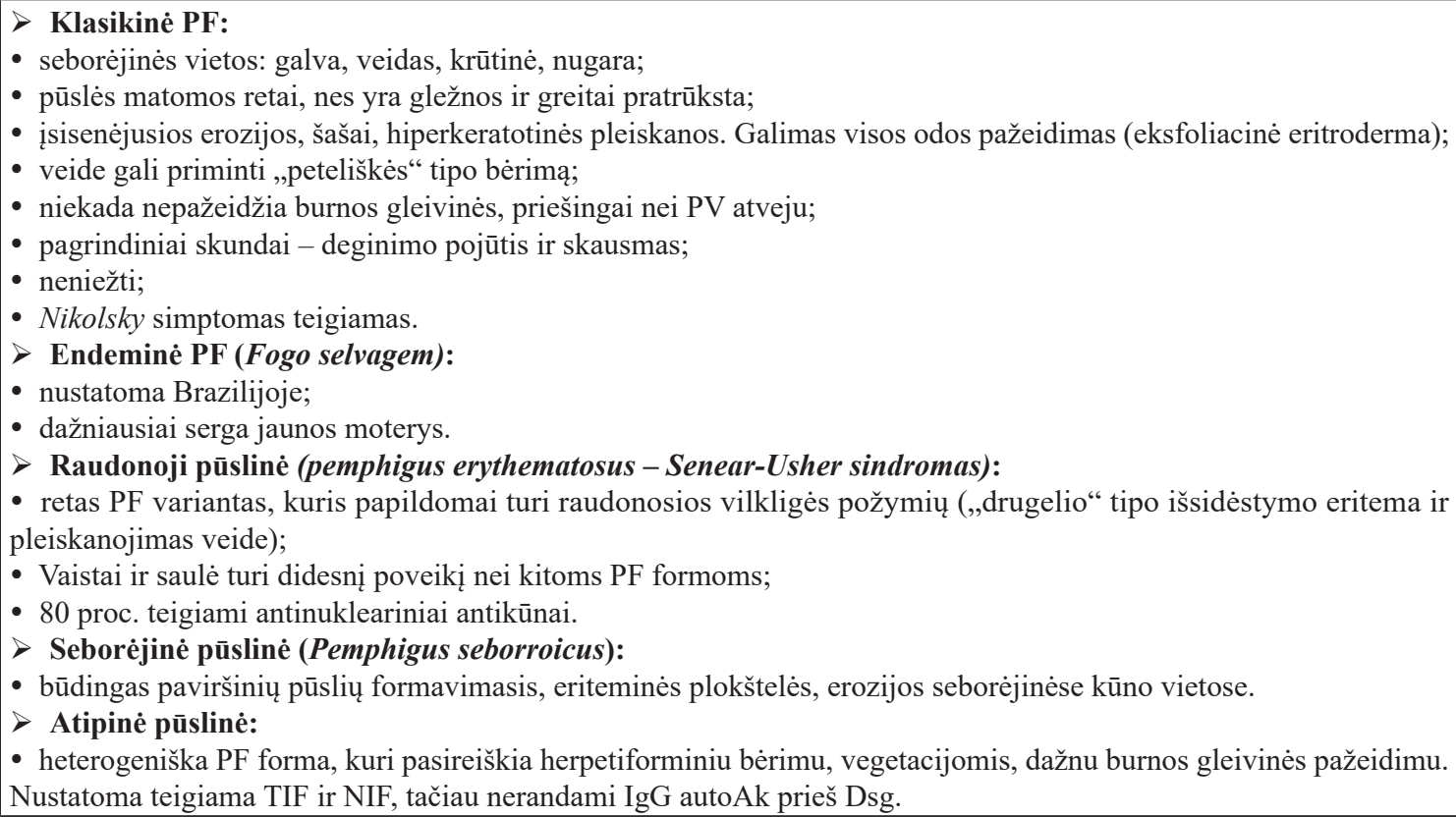 \\
\hline
\end{tabular}

\section{Tyrimo objektas ir metodika}

Atlikta mokslinès literatūros, publikuotos 2010 - 2016 m., apžvalga ir sisteminè analizè. Mokslinès literatūros šaltinių ieškota duomenų bazėse: PubMed, Medscape, Cohrane, Medline. Naudoti raktažodžiai: ,,pemphigus “, ,, autoantibody", ,, desmogleins “, ,,immunofluorescence “, „pemphigus vulgaris “, „pemphigus foliaceus", "paraneoplastic pemphigus ", , systemic corticosteroids “.
Pemphigus etiologija ir patogenezè. Pemphigus - tai heterogeniška autoimuninè odos ir gleivinių liga, susijusi su autoantikūnų (autoAk) imunoglobulino $\mathrm{G}(\mathrm{IgG})$ ir imunoglobulino A (IgA) gamyba prieš skirtingas adhezijos molekules epidermyje ir pasireiškianti intraepiderminèmis akantolitinėmis pūslèmis. Pemphigus grupèje dažniausiai diagnozuojama paprastoji pūslinè (pemphigus vulgaris (PV). Sergamumas šia liga siekia 2 naujus atvejus $1 \mathrm{mln}$. gyventojų $[4,5]$. 


\section{1 lentelès tęsinys}

\begin{tabular}{|c|c|}
\hline 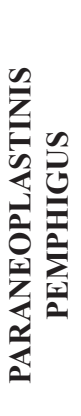 & $\begin{array}{l}\text { PP: } \\
\text { - susijusi su piktybiniais limfoproliferaciniais procesais, dažniausiai ne-Hodžkino limfoma, lėtine limfocitine leukemija, } \\
\text { tymoma ar su Kastelmano liga; } \\
\text { - cheilitas, progresuojantis hemoraginis stomatitas, labai skausmingos erozijos, polimorfinis odos bėrimas: ị daugia- } \\
\text { formę eritemą, pūslinị pemfigoidą panašūs bėrimai. Disfagija, randèjantis konjunktyvitas, keratitas; } \\
\text { - bloga ar greita letali baigtis esant bėrimams, panašiems ị daugiaformès eritemos bèrimus; } \\
\text { - delnų ir padų lichenoidinė egzantema; } \\
\text { - atsparumas gydymui; } \\
\text { - remisija galima tik ekskliudavus piktybinị procesą; } \\
\text { - pastaruoju metu PP vis dažniau ịvardijama kaip daugiažidininio paraneoplastinio autoimuninio sindromo pasireiš- } \\
\text { kimas odoje ir gleivinėse. }\end{array}$ \\
\hline 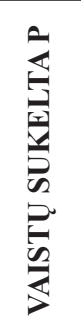 & $\begin{array}{l}\text { - Dažniausiai šią ligą lemiantys vaistai: } \\
\text { - turintys sulfhidrilinę grupę (kaptoprilis, D-penicilaminas, piroksikamas); } \\
\text { - turintys fenolio žiedą; } \\
\text { - netioliniai ir nefenoliniai (angiotenziną konvertuojančio fermento inhibitoriai, nesteroidiniai vaistai nuo uždegimo, } \\
\text { nifedipinas, skiepai, interferonas ir kiti citokinai); } \\
\text { - pasireiškia PV būdingais bėrimais; } \\
\text { - pasveikstama nutraukus šių vaistų vartojimą. }\end{array}$ \\
\hline 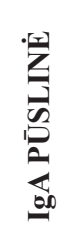 & $\begin{array}{l}\text { - Būdingos gležnos pūslès ir pustulès eriteminès, pleiskanojančios odos fone; } \\
\text { - bėrimai dažnai susilieja ị didelius plotus ir formuoja žiedines infiltruotas plokšteles, akcentuotais kraštais, padengtais } \\
\text { pleiskana, ịcentriškai laisvu kraštu; } \\
\text { - bérimai daugiausia lokalizuojasi apatiniame liemens ir viršutiniuose galūnių trečdaliuose bei raukšlèse; } \\
\text { - nebūdingas gleivinių pažeidimas. }\end{array}$ \\
\hline
\end{tabular}

Autoimunių ligų etiologija iki šiol nėra aiški. PV atveju nustatyta genetine predispozicija HLA - DRQ402 - DQO505 [6].

Terminas pemphigus kilęs iš graikų kalbos žodžio pemphix, kuris reiškia - pūslè. Pemphigus pavadinimo kilmè siekia 1768 metus, kuomet žymus prancūzų kilmès gydytojas Francois Boissier de Sauvages pirmą kartą paminèjo ji veikale - "Nosologia Methodica..." [7-9]. Dar daugiau apie šią ligą sužinoma 1964 metais, E.H. Beutner ir R.E Jordon nustačius sergančiųų pemphigus serume cirkuliuojančius autoAk prieš keratinocito paviršiuje esančias sudètines dalis. 1990 metais nustatyta, kad šių autoAk taikinys - desmosomų struktūriniai baltymai - desmogleinai (Dsg), priklausantys kadherinų klasei. Elektroninès mikroskopijos būdu pastebèta, kad esant spongiozei, pavyzdžiui, sergant alerginiu kontaktiniu dermatitu, dèl edemos keratinocitai nutolsta vienas nuo kito, tačiau desmosomų dẻka adhezija išlieka. Tik tuomet, kai desmosomos suardomos, ivvyksta akantolizè, formuojasi spongiozinè pūslè. Dsg rasti ne tik epidermyje, bet ir kituose audiniuose (žarnyne, pieno liaukose, trachejjoje, tulžies pūsleje, kepenyse, širdyje ir užkrūčio liaukoje) [10]. Pūslinių ligų patogenezèje svarbiausias vaidmuo tenka desmogleinui 1 (Dsg1) ir desmogleinui 3 (Dsg3). Sergant PV, lakštine pūsline (pemphigus foliaceus (PF), paraneoplastine pūsline (PP) susidaro autoAk prieš Dsg1, kurio daugiausia randama epidermio paviršiniuose sluoksniuose. O sergant PV, kai pažeidžiamos ir gleivinès, nustatomi AutoAk ir prieš Dsg3, kuris randamas giliuosiuose epidermio sluoksniuose. Dsg3 daugiausia yra gleivinèse (1 pav.) [11-13]. Nustatyta, kad esant aukštam anti-Dsg1 titrui, ligos atkryčiai dažnesni, o anti-Dsg3 titras nekoreliuoja su ligos atkryčiais [1].

Klasifikacija. Pemphigus klasifikuojama ị keletą nozologinių vienetu, kurie tarpusavyje skiriasi patogeneze, bėimo pobūdžiu, lokalizacija bei autoAk prisijungimo vieta odoje (1 lentelè).

I. Paprastoji:

- klasikiné;

- vegetacinè.

II. Lakštinè:

- klasikiné;

- endeminè (Fogo Selvagem);

- raudonoji (Senear - Usher);

- seborèjinè pūslinè (Pemphigus seborrhoicus); 
2 lentelè. Pemphigus klinikinių formų histologinio ir imunologinių tyrimų duomenys [1, 3, 4, 14, 21$]$.

\begin{tabular}{|c|c|c|c|}
\hline HISTOPATOLOGIJA & TIF & NIF & ELISA \\
\hline \multicolumn{4}{|c|}{$\begin{array}{ll} & \text { PAPRASTOJI PŪSLINE் } \\
\end{array}$} \\
\hline $\begin{array}{l}\text { Intraepitelinè separacija (virš bazinės } \\
\text { membranos), akantolizè - laisvi baza- } \\
\text { linio sluoksnio keratinocitai dermos } \\
\text { ir epidermio jungties vietoje (pūslès } \\
\text { dugnas). Senesnèse pūslèse - neutro- } \\
\text { fillų ir eozinofilų infilttracija. }\end{array}$ & $\begin{array}{l}\text { Pažeidimas virš pamati- } \\
\text { nio epidermio sluoksnio. } \\
\text { Intraepiderminiai IgG } \\
\text { (+/- C3) depozitai su tarpląs- } \\
\text { teliniu švytėjimu. }\end{array}$ & $\begin{array}{l}\text { IgG autoAk jungimasis } \\
\text { prie epitelinių ląstelių su } \\
\text { tarpląsteliniu švytėjimu. }\end{array}$ & $\begin{array}{l}\text { IgG autoAk, specifiniai Dsg3 (gleivinių } \\
\text { PV), +/- Dsg } 1 \text { (odos ir gleivinių PV), } \\
\text { retai nustatomi autoAk prieš desmoko- } \\
\text { liną 3, acetilcholino alfa } 9 \text { receptorių, } \\
\text { pemfaksiną. }\end{array}$ \\
\hline \multicolumn{4}{|c|}{ LAKŠTINE் PŪSLINE் } \\
\hline Poraginès pūslès su akantolize. & $\begin{array}{l}\text { Poraginio sluoksnio akcenta- } \\
\text { vimas. Intraepiderminiai IgG } \\
\text { (+/- C3) depozitai su } \\
\text { tarpląsteliniu švytèjimu. }\end{array}$ & $\begin{array}{l}\text { Poraginio sluoksnio } \\
\text { akcentavimas. Intraepi- } \\
\text { derminiai IgG } \\
(+/- \text { C3) depozitai su } \\
\text { tarpląsteliniu švyte- } \\
\text { jimu. }\end{array}$ & AutoAk prieš Dsg1. \\
\hline \multicolumn{4}{|c|}{ PARANEOPLASTINÉ PŪSLINÉ } \\
\hline $\begin{array}{l}\text { Intraepitelinè separacija (virš bazinès } \\
\text { membranos), akantolizè - laisvi baza- } \\
\text { linio sluoksnio keratinocitai dermos } \\
\text { ir epidermio jungties vietoje (pūslès } \\
\text { dugnas). } \\
\text { Senesnèse pūslèse - neutrofilų ir eo- } \\
\text { zinofilų infiltracija. }\end{array}$ & $\begin{array}{l}\text { Tarpląstelinis IgG (+/- C3) } \\
\text { depozitų švytèjimas epider- } \\
\text { myje bei linijinis švytejjimas } \\
\text { palei bazinę membraną. }\end{array}$ & $\begin{array}{l}\text { IgG autoAk jungimasis } \\
\text { prie epitelinių ląstelių su } \\
\text { tarpląsteliniu švytèjimu. }\end{array}$ & $\begin{array}{l}\text { IgG autoAk prieš } 1-3 \text { desmokoliną, } \\
\text { desmoplakiną I ir desmoplakiną } \\
\text { II, envoplakiną bei periplakiną, ì } \\
\text { alfa-2-makroglobuliną panašų proteiną, } \\
\text { kartais gali būti nustatomi autoAk prieš } \\
\text { plektiną, } 230 \mathrm{kDa} \text { pūslinio pemfigoido } \\
\text { antigeną. }\end{array}$ \\
\hline \multicolumn{4}{|c|}{ IgA PŪSLINE் } \\
\hline $\begin{array}{l}\text { Intraepiderminès pustulès su neiš- } \\
\text { reikšta akantolize ir neutrofillu infiltra- } \\
\text { tais epidermyje ir viršutinejje dermoje. }\end{array}$ & $\begin{array}{l}\text { Dominuoja IgA depozitai, } \\
\text { kartais IgG, C3 depozitai. In- } \\
\text { traepiderminės neutrofilinès } \\
\text { dermatozės atveju - apatinio } \\
\text { ar viso epidermio paviršiuje, } \\
\text { subkorenalinės pustulinės } \\
\text { dermatozès atveju - viršuti- } \\
\text { niame epidermio sluoksnyje. }\end{array}$ & $\begin{array}{l}\text { IgA autoAk jungimasis } \\
\text { prie epitelinių ląstelių su } \\
\text { tarpląsteliniu švytèjimu. }\end{array}$ & $\begin{array}{l}\text { IgA autoAk prieš } 1 \text { desmokoliną, Dsg1- } \\
3 \text {. }\end{array}$ \\
\hline
\end{tabular}

- atipinè pūslinè.

III. Paraneoplastinè pūslinė (priklauso paraneoplastiniam autoimuniniam sindromui).

IV. Vaistų sukelta pūslinè.

V. IgA pūslinè:

- intraepiderminé neutrofilinè dermatozé;

- poraginè pustuliné dermatozè $[10,13,6]$.

Pemphigus diagnostikos principai. Pemphigus diagnozè nustatoma remiantis anamneze, klinika bei laboratoriniu tyrimų rezultatais. "Auksiniu standartu" pemphigus diagnostikoje išlieka tiesioginès imunofluorescencijos mikroskopija (TIF), kuri būtina diagnozei patvirtinti, tačiau netinkama tolimesnei ligos kontrolei. AutoAk specifiškai jungiasi tam tikrose epidermio vietose, nuo to priklauso švytèjimo tipas, reikalingas diagnozei nustatyti [4]. Pemphigus ligų grupei būdingi autoAk, kurie prisijungia prie epidermio ląstelių, todèl randami intraląsteliniai (,, net like ") depozitai epidermyje $[4,3]$. Netiesioginè imunofluorescencija (NIF) parodo
autoAk, cirkuliuojančius paciento kraujyje [3]. NIF, atliktoje ant bezdžionės stemplès ar sveiko žmogaus odos, būdingas švelnus tinkliškas epidermio keratinocitų švytëjimas, vadinamas „medaus korio“ ar ,žuvies tinklo“ vaizdas [1, 14].

Serologiniai testai (ELISA, imunoblotas, imunoprecipitacijos analizè) - tai paskutinis diagnozès nustatymo žingsnis. Šiuo metu naudojamos ịvairios diagnostinès sistemos nustatyti IgG ar IgA antikūnus (prieš Dsg1, Dsg3, envoplakiną, periplakiną) paciento kraujyje. ELISA tyrimo privalumas - tiksliai parodo paciento kraujyje cirkuliuojančius autoAk, be to, šis tyrimo metodas gali būti naudojamas gydymo kontrolei, ligos eigos, atsako ì gydymą îvertinimui, norint sumažinti skiriamų vaistų dozę ar nutraukti gydymą. Diagnozei nustatyti ar patikslinimui ELISA atliekamas kartu su TIF ir/ar NIF tyrimais. Siekiant išvengti klaidingai neigiamų histopatologinių tyrimų atsakymų, pirmiausia reikia teisingai atlikti odos ir gleivinių biopsiją (2 pav.) Taikoma stulpelinė biopsijos paèmimo technika su $4 \mathrm{~mm}$ skersmens 
3 lentelè. Pemphigus sisteminis gydymas [1, 4, 10, 15, 21].

\begin{tabular}{|c|c|c|c|}
\hline VAISTAS & DOZE் & ŠALUTINIS POVEIKIS & YPATUMAI \\
\hline $\begin{array}{l}\text { Sisteminiai KS - pre- } \\
\text { dnizolonas }\end{array}$ & $\begin{array}{l}0,5-1,5 \mathrm{mg} / \\
\mathrm{kg} / \mathrm{d} .\end{array}$ & $\begin{array}{l}\text { Odos atrofija, osteoporozè, glau- } \\
\text { koma, virškinamojo trakto opos, } \\
\text { Kušingo sindromas, edema, cukrinis } \\
\text { diabetas, hipertenzija. }\end{array}$ & $\begin{array}{l}\text { - Teigiamas efektas } 2 \text { savaitės pabaigoje (2 savaičių } \\
\text { eigoje neatsiradus naujų bėrimų), vėliau dozė maži- } \\
\text { nama } 5 \mathrm{mg} / \mathrm{sav} \text {. iki } 30 \mathrm{mg} / \mathrm{d} \text {. } \\
\text { - Nesulaukiant teigiamo efekto, dozė gali būti didi- } \\
\text { nama iki } 2 \mathrm{mg} / \mathrm{kg} / \mathrm{d} \text {. } \\
\text { - Papildomai skirti protonų siurblio inhibitorius ar H2 } \\
\text { blokatorius, vitaminą D ir kalcio preparatus. } \\
\text { - Moterims postmenopauzės periodu ir vyrams, vyres- } \\
\text { niems nei } 50 \text { metų, skiriant KS > } 3 \text { mėn., rekomen- } \\
\text { duojamas gydymas bifosfonatais. } \\
\text { - Esant trombozių rizikai, papildomai būtina antitrom- } \\
\text { bozinė profilaktika. } \\
\text { - KS injekcijos vietiškai rekomenduojamos izoliuo- } \\
\text { tiems burnos gleivinės, lūpų ar odos pažeidimams. } \\
\text { - Pulsinė kortikosteroidų terapija rekomenduojama } \\
\text { tik labai sunkiais atvejais. } \\
\text { - Lakštinės pūslinės gydymui dažniausiai pakanka } \\
\text { mažesnių dozių. } \\
\text { - Sisteminiai KS dažniausiai derinami su kitais imu- } \\
\text { nosupresiniais vaistais, iš kurių pirmiausia pasirenka- } \\
\text { mas - AZA. }\end{array}$ \\
\hline Azatioprinas & $\begin{array}{l}1-3 \mathrm{mg} / \mathrm{kg} / \mathrm{d} \\
\text { (priklauso nuo } \\
\text { TPMT akty- } \\
\text { vumo) }\end{array}$ & $\begin{array}{l}\text { Agranulocitozė dėl toksinès mie- } \\
\text { losupresijos, esant TPMT stokai } \\
\text { (dažnesnės infekcijos, onkologiniai } \\
\text { susirgimai), hepatotoksiškumas, } \\
\text { virškinimo trakto sutrikimai, nef- } \\
\text { ropatija. }\end{array}$ & $\begin{array}{l}\text { - AZA kartu su KS - standartinis gydymas, sergant } \\
\text { vidutinio sunkumo ir sunkia pūsline liga. } \\
\text { - Rekomenduojama pradėti nuo } 50 \mathrm{mg} / \mathrm{d} \text {., įsitikinus, } \\
\text { kad nėra idiosinkrazinių reakcijų, dozę didinti iki pa- } \\
\text { geidaujamos. } \\
\text { - Greitesnė ligos remisija, derinant kartu su KS; } \\
\text { - Pasižymi šalutinį KS poveikį mažinančiu efektu; } \\
\text { - Teigiamas efektas po 3-6 sav. } \\
\text { - TPMT nustatymas prieš gydymą. Esant aukštam } \\
\text { TPMT aktyvumui, gali būti skiriama maksimali dozė, } \\
\text { jei TPMT vidutinis ar žemas, skiriama dozė } 0,5-1,5 \\
\text { mg/kg/d. } \\
\text { - BKT, kepenų fermentų tyrimai. } \\
\text { - Kontracepcija gydymo metu ir } 3 \text { mėn. po gydymo. } \\
\text { - Mažinant KS dozes, AZA dozė išlieka tokia pat. }\end{array}$ \\
\hline
\end{tabular}

prakalo (punch) adata. Reikalingos dvi biopsijos. Pirmoji - histopatologiniam ištyrimui. Esant mažai pūslei, biopsija imama apimant visą pūslę. Jei pūslè didelè, biopsija atliekama paimant dali pūslès ir greta esančios sveikos odos. Biopsinè medžiaga transportuojama 4 proc. formalino tirpale. Kitokie biopsijos paėmimo principai galioja atliekant TIF. Šiuo atveju odos gabalèlis imamas iš sveikos ar eriteminès odos, šalia pūslès, ne toliau nei $1 \mathrm{~cm}$ atstumu, nes imunoglobulinai bei komplementas yra suardomi uždegiminès reakcijos ir jų nebeịmanoma nustatyti pūslèje. Paimta biopsiné medžiaga TIF tyrimui dedama ị fiziologinị 0,9 proc. $\mathrm{NaCl}$ tirpalą ar Michel'io terpę ir per 2 val. turi būti ištiriama [4].
Pemphigus gydymo ypatumai. Autoimuninių pūslinių ligų gydymas yra sudètingas ir ilgalaikis. Pemphigus eiga dažniausiai lètinè, recidyvuojanti, todèl labai svarbi klinikinè simptomų kontrolè, pasirinkto gydymo efektyvumo vertinimas. Pasiekus ligos kontrolę - laipsniškas imunosupresantų nutraukimo, palaikomojo gydymo trukmès planavimas ar jo nutraukimo rizikos įvertinimas.

Pagrindiniai tikslai diagnozavus pemphigus:

- pūslinio pažeidimo ir funkcinio sutrikimo, susijusio su liga, gydymas;

- ligos atsinaujinimo kontrolè;

- dažniausių šalutinių reiškinių, susijusių su ilgalaikiu 


\section{3 lentelès tęsinys}

\begin{tabular}{|c|c|c|c|}
\hline $\begin{array}{l}\text { Mikofenolato } \\
\text { mofetilis }\end{array}$ & $1-2 \mathrm{~g} / \mathrm{d}$. & $\begin{array}{l}\text { Inkstų nepakankamumas, pancito- } \\
\text { penija, virškinimo trakto sutrikimai, } \\
\text { hepatotoksiškumas, elektrolitų dis- } \\
\text { balansas. }\end{array}$ & $\begin{array}{l}\text { - Monoterapija galima, sergant lengva forma. } \\
\text { - Pasižymi šalutini KS poveikị mažinančiu efektu. } \\
\text { - Esant virškinamojo trakto sutrikimams, siūloma } \\
\text { keisti i natrio mikofenolatą. } \\
\text { - Dèl galimos neutropenijos būtina bendro kraujo ty- } \\
\text { rimo (BKT) kontrolè. } \\
\text { - Šis vaistas pasižymi mažesniu mielosupresiniu ir } \\
\text { hepatotoksiniu poveikiu nei AZA. }\end{array}$ \\
\hline Mikofenolinė rūgštis & \multicolumn{2}{|l|}{$1440 \mathrm{mg} / \mathrm{d}$. } & $\begin{array}{l}\text { - Dozė didinama po } 1 \text { kapsulę/sav., norint išvengti } \\
\text { virškinimo trakto veiklos sutrikimo. }\end{array}$ \\
\hline Ciklofosfamidas & $\begin{array}{l}100-200 \mathrm{mg} / \mathrm{d} . \\
\text { ar bolusas } \mathrm{i} / \mathrm{v} .\end{array}$ & $\begin{array}{l}\text { Labai toksiškas. Vèmimas, pykini- } \\
\text { mas, diareja, skrandžio skausmas, } \\
\text { hemoraginis cistitas, odos patamsè- } \\
\text { jimas, alopecija, amenoreja, nevai- } \\
\text { singumas. }\end{array}$ & $\begin{array}{l}\text { - Pasižymi imunusupresiniu, antineoplastiniu povei- } \\
\text { kiu. } \\
\text { • Skiriamas kartu KS, kai su kitais vaistais nepasie- } \\
\text { kiama remisija. }\end{array}$ \\
\hline Metotreksatas (MTX) & $10-20 \mathrm{mg} / \mathrm{sav}$. & $\begin{array}{l}\text { Pancitopenija, stomatitas, hepato/ } \\
\text { nefropatija, virškinimo trakto su- } \\
\text { trikimai, } \\
\text { egzantemos, galvos skausmas, alo- } \\
\text { pecija, intersticinis pneumonitas, } \\
\text { nevaisingumas, teratogeniškumas. }\end{array}$ & $\begin{array}{l}\text { - Kitą dieną skiriama folio rūgštis }(5-15 \mathrm{mg} / \mathrm{d} \text {.). } \\
\text { - Pasižymi labiau priešuždegiminiu nei imunosupre- } \\
\text { siniu poveikiu. } \\
\text { - Skiriama, kai KS kontraindikuotini. } \\
\text { - Rekomenduojamas vyresniems ir daugybinèmis gre- } \\
\text { tutinėmis ligomis sergantiems pacientams; } \\
\text { - BKT, kepenų, inkstų rodiklių kontrolè. }\end{array}$ \\
\hline Ciklosporinas & $2,5-5 \mathrm{mg} / \mathrm{kg} / \mathrm{d}$. & $\begin{array}{l}\text { Arterinė hipertenzija, nefrotoksišku- } \\
\text { mas, virškinimo trakto sutrikimai, } \\
\text { hiperurikemija, galvos skausmai, hi- } \\
\text { pertrofinis gingivitis, hipertrichoze, } \\
\text { mialgijos, parestezijos. }\end{array}$ & $\begin{array}{l}\text { - Kontraindikuotinas esant hiperurikemijai, hiperka- } \\
\text { lemijai. } \\
\text { - Arterinio kraujo spaudimo (AKS), kreatinino, ciklos- } \\
\text { porino koncentracijos kraujyje kontrolè. }\end{array}$ \\
\hline Dapsonas & $1-2 \mathrm{mg} / \mathrm{kg} / \mathrm{d}$ & $\begin{array}{l}\text { Methemoglobinemija, hemolizinè } \\
\text { anemija, galvos skausmas, virš- } \\
\text { kinimo trakto sutrikimai, cianozé, } \\
\text { agranuliocitozė, hepato/nefropatija. }\end{array}$ & $\begin{array}{l}\text { - Būdingas priešuždegiminis poveikis. } \\
\text { - Veiksmingumas - } 84 \text { proc. } \\
\text { - PF atveju ypač efektyvus. } \\
\text { - Prieš skiriant - G6PD, bilirubino, retikuliocitų kie- } \\
\text { kis. } \\
\text { - BKT, methemoglobino kontrolè. } \\
\text { - Folinè rūgštis hemolizinès anemijos profilaktikai. }\end{array}$ \\
\hline $\begin{array}{l}\text { Intraveninis imuno- } \\
\text { globulinas (IVIg) }\end{array}$ & $\begin{array}{l}400 \mathrm{mg}-2 \mathrm{~g} / \mathrm{kg} / \\
\text { ciklui (ciklas }- \\
\text { dozè dalijama ì } \\
3 \text { dalis ir sulei- } \\
\text { džiama per } 3 \mathrm{~d} . \\
\text { iš eilès). } \\
1 \text { ciklas kartoja- } \\
\text { mas kas } 3-4 \text { sav. } \\
\text { Infuzija atlie- } \\
\text { kama per } 4-5 \\
\text { val. }\end{array}$ & $\begin{array}{l}\text { Anafilaksinè reakcija, karščiavimas, } \\
\text { galvos skausmas, hipotenzija, viršk. } \\
\text { trakto sutrikimai, aseptinis meningi- } \\
\text { tas, didesnè tromboembolijų rizika } \\
\text { dèl padidejjusio viskoziškumo, ūmi- } \\
\text { nis inkstų nepakankamumas, hemo- } \\
\text { lizè, egzantema. }\end{array}$ & $\begin{array}{l}\text { - Pasižymi priešuždegiminiu ir imunomoduliaciniu } \\
\text { poveikiu. } \\
\text { - Galima hiperjautrumo reakcija, esant IgA trūkumui, } \\
\text { todèl nustačius būtina premedikacija ir aktyvus ste- } \\
\text { bėjimas. }\end{array}$ \\
\hline
\end{tabular}

gydymu sisteminiais kortikosteroidais (KS) ir imunosupresantais sumažinimas;

- paciento gyvenimo kokybės gerinimas.

Europos dermatologų forumo (EDF) ir Europos dermatovenerologu asociacijos (EADV) pemphigus diagnostikos ir gydymo gairèse pirmo pasirinkimo vaistais gydant šią ligą išlieka KS (3 lentelè) [4]. Tačiau ilgalaikis jų vartojimas susijęs su daugybe šalutinių reiškinių (sunkios infekcijos, virškinimo trakto opos, hiperglikemija, hiperlipidemija, hipertenzija, steroidų sukelta miopatija, kognityviniai sutrikimai, osteoporozė, trombembolinès komplikacijos), kurių iš dalies išvengti galima kombinuojant su imunosupresiniais 


\section{3 lentelès tęsinys}

\begin{tabular}{|c|c|c|c|}
\hline $\begin{array}{l}\text { Plazmaferezé } \\
\text { Imunoadsorbcija }\end{array}$ & $\begin{array}{l}3-4 \mathrm{k} / \mathrm{sav} . \mathrm{kas} \\
3-4 \mathrm{sav} .\end{array}$ & $\begin{array}{l}\text { Anafilaksinè reakcija, hipogamaglo- } \\
\text { bulinemija. }\end{array}$ & $\begin{array}{l}\text { - Greičiau pasiekiama ligos kontrolè. } \\
\text { - Mažinama IgG prieš Dsg1 ir Dsg3 koncentracija } \\
\text { serume. } \\
\text { - Skiriama tais atvejais, kai gydymas KS neefektyvus, } \\
\text { kartu su rituksimabu ar ciklofosfamidu. } \\
\text { - Kontraindikacijos: sunkios sisteminės infekcijos, } \\
\text { kardiovaskulinės ligos, AKFI vartojimas, išplitusi he- } \\
\text { moraginė diatezè. } \\
\text { · Plazmaferezės metu imunoglobulinų pašalinimas } \\
\text { nespecifinis. } \\
\text { - Imunoadsorbcijos metu pašalinami specifiški imu- } \\
\text { noglobulinai, pasirenkant atitinkamą filtrą. }\end{array}$ \\
\hline Rituksimabas & $\begin{array}{l}375 \mathrm{mg} / \mathrm{m}^{2} / \mathrm{sav} . \\
-4 \text { sav. } \\
\text { (kas } 2 \text { sav.) }\end{array}$ & $\begin{array}{l}\text { Pykinimas, niežejjimas, angio- } \\
\text { edema, astenija, hipotenzija, } \\
\text { galvos skausmas, bronchospaz- } \\
\text { mas, rinitas, dilgèlinė, dermatitas, } \\
\text { mialgija, hipertenzija - po } 30-120 \\
\text { min. pradejus infuziją, viršk. trakto } \\
\text { sutrikimai, ŠN, aritmija, pancito- } \\
\text { penija, neuropatija, multifokalinè } \\
\text { leukoencefalopatija. }\end{array}$ & $\begin{array}{l}\text { Monokloninis Ak prieš B limfocitų CD } 20 \text { antigenus; } \\
\text { Atsakas po } 3 \text { mèn. } \\
\text { - Sunkiais atvejais - kombinacija su IVIg ekstrakor- } \\
\text { porine imunoadsorbcija. }\end{array}$ \\
\hline
\end{tabular}

vaistais ir pasiekti klinikinę remisiją mažiausiomis KS dozèmis [15].

Pirmo pasirinkimo adjuvantu rekomenduojamas azatioprinas (AZA) arba mikofenolato mofetilis ar mikofenoline rūgštis. Trečio pasirinkimo gydymui (kai yra kontraindikacija KS arba gydymui atspari pemphigus) - intraveninis imunoglobulinas (IVIg), imunoadsorbcija, dapsonas, metotreksatas, anti CD 20 monokloninis autoantikūnas (rituksimabas) $[1,10]$.

KS gali būti iš karto derinami su imunosupresiniais vais-

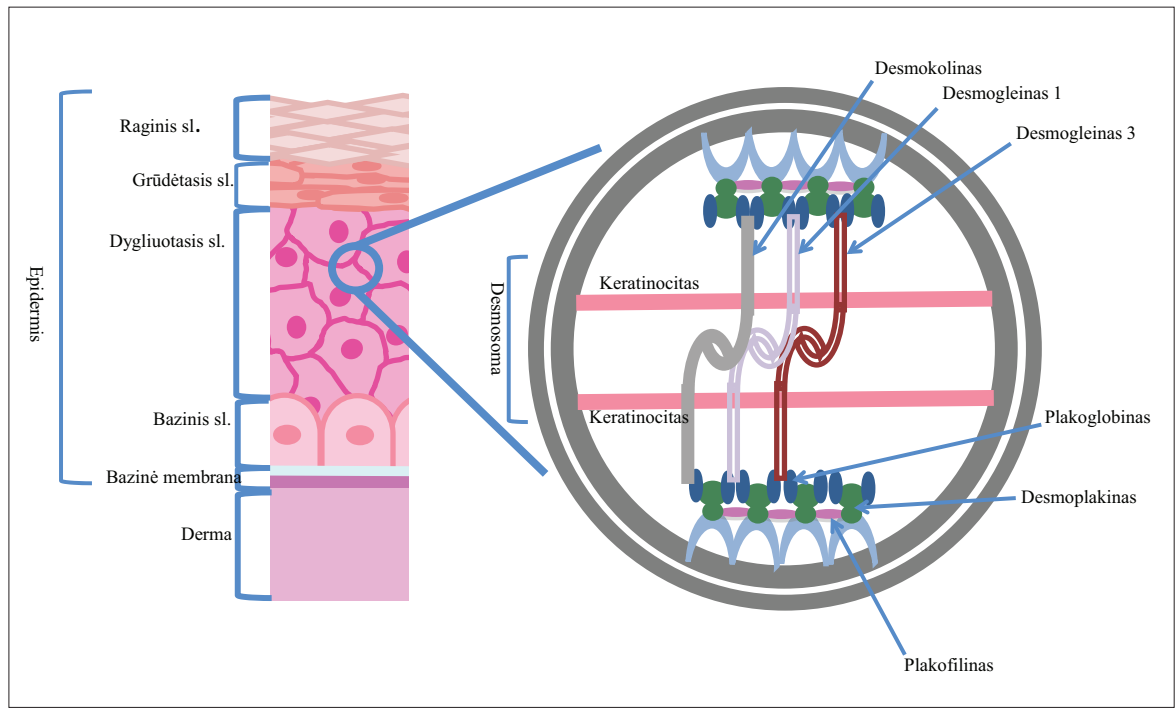

1 pav. Adhezijos molekulès epidermyje tais tais atvejais, kai yra komplikacijų rizika dèl ilgo KS vartojimo ( $>4$ mènesius) ir jei skiriama pradinè dozè didesnè nei minimali dienos norma ( $>10 \mathrm{mg} / \mathrm{d}$.).

Nors sisteminių kortikosteroidų ir imunosupresinių vaistų atsiradimas 20-ojo amžiaus viduryje dramatiškai pakeitė pūslinių ligų eigą ir baigtị, tačiau iki šiol išlieka gana aukštas mirtingumo lygis (5-11 proc.), susijęs su gydymo komplikacijomis [15]. Kad būtų išvengta su gydymu susijusių galimų komplikacijų, būtinas prieš gydymą ir gydymo metu kruopštus paciento bendras klinikinès būklès ịvertinimas ir esant reikalui savalaikè gydymo korekcija.

Prieš skiriant gydymą rekomenduojama:

- kruopšti anamnezè ir klinikinis ištyrimas dèl galimų rizikos veiksnių, gretutinių ar kitų autoimuninių ligų;

- prognozès îvertinimas, atsižvelgiant ị paciento amžių ir bendrą būklę (Karnofsky indeksas);

- pažeidimo išplitimo ir pasiskirstymo nustatymas, vadovaujantis autoimuninių pūslinių ligų intensyvumo ir sunkumo indeksu (ABSIS) arba pemphigus aktyvumo ir ploto indeksu (PDAI);

- bendras kraujo tyrimas (BKT); 
- kreatininas, elektrolitai;

- transaminazès, gammagliutamil transpeptidazè (GGT), šarminè fosfataze (ŠF);

- bendras serumo baltymas, albuminai;

- gliukozé;

- ištyrimas dèl hepatitų B, C, ŽIV infekcijos;

- krūtinès ląstos rentgenograma;

- vidaus organų sonoskopija.

Tyrimai pagal indikacijas:

- serumo IgA nustatymas prieš skiriant intraveninị imunoglobuliną;

- tiopurino metiltransferazès (TPMT) nustatymas prieš skiriant AZA;

- kvantiferono ar Mantu tyrimai tuberkuliozės ekskliudavimui;

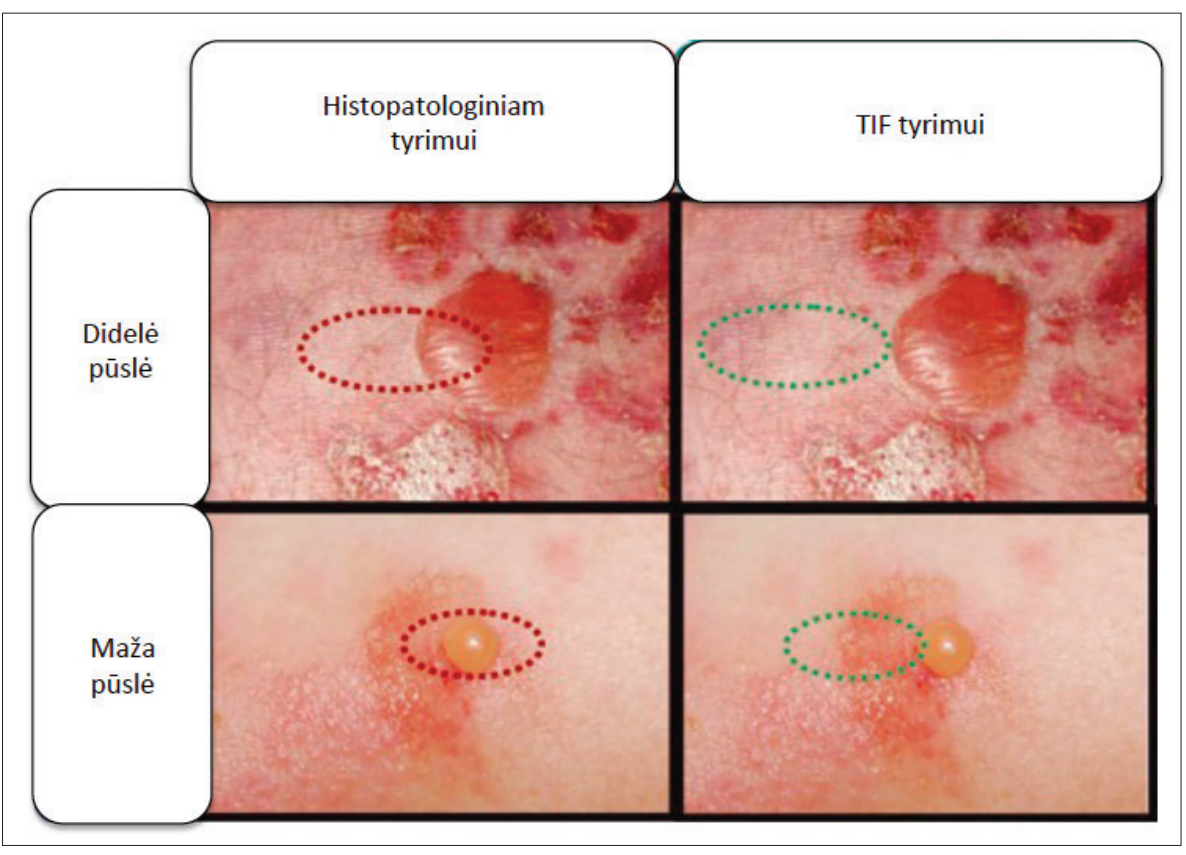

2 pav. Biopsijos ėmimo vieta

- gliukozės-6-fosfatdehidrogenazès (G6PD), bilirubino, retikuliocitų kiekis prieš skiriant dapsoną;

- nëštumo testas;

- osteodensitometrija prieš skiriant KS;

- okulisto konsultacija (glaukomos, kataraktos ekskliudavimui) [4].

Kartu su sisteminiu imunosupresiniu gydymu gali būti skiriamas vietinis gydymas. Esant skausmingiems gleivinès pažeidimams, orofaringinèms erozijoms skiriamas KS gelis ar skalavimo skystis, dekspantenolio, antiseptikų turintys sudètiniai vaistai. Izoliuotiems burnos gleivinès pažeidimams - triamcinolone acetonide injekcijos ị pažeidimo vietą. Stiprūs vietiniai KS (Clobetasol propionate) ar kalcineurino inhibitoriai, pavilgai, emolientai skiriami odos pažeidimams. Akių pažeidimams rekomenduojami akių lašai su KS ar ciklosporinu, gydytojo oftalmologo kontrolè.

Dèl epidermio barjero pažeidimo ir imunosupresinio gydymo dažnai neišvengiamos oportunistinès infekcijos (bakterinès, virusinès, grybelinès, parazitinès). Literatūros duomenimis, sergant pemphigus, šių infekcijų dažnis siekia $60-68$ proc. Neretai šios infekcijos sukelia sunkias komplikacijas ir gali lemti fatalinę baigti [2]. Antrinių infekcijų profilaktikai skiriamos vonios su antiseptikais, vietiniai antiseptikai ir antibiotikai, antivirusinis gydymas herpetinès infekcijos profilaktikai. Kandidozių profilaktikai - antigrybeliniai vaistai [6].

Didelè imunosupresantų dozé ar ilgalaikis jų vartojimas didina navikų vystymosi riziką, ypač odos, todèl būtina

apsauga nuo ultravioletinių spindulių (21). Tokių pacientų skiepijimas gyvomis vakcinomis - kontraindikuotinas, negyvomis vakcinomis - galimas, tačiau yra duomenų, kad mažiau efektyvus $[1,4,16]$.

Yra tyrimų, rodančių, kad pacientams, sergantiems PV, iki pradedant gydymą, nustatoma ryškiai sumažejusi vitamino D koncentracija. Tačiau iki šiol nepagrịsta ịtaka ligos patofiziologiniam mechanizmui [17]. Būtina perspèti pacientus vengti per ilgo buvimo saulèje, nevalgyti labai karšto, aštraus maisto, prieš vartojant bet kokius papildomus vaistus pasitarti su savo gydytoju, vengti didelio streso [10].

Skiriant ilgalaiki gydymą sisteminiais KS, būtina:

- osteoporozès profilaktika;

- gydymas mažiausiomis KS dozèmis;

- vitamino D, Ca preparatai;

- bifosfatai (alendronate, risedronate) moterims postmenopauzès laikotarpiu, $>50 \mathrm{~m}$. amžiaus vyrams arba kai KS gydoma > 3 mèn.;

- kandidozių profilaktika;

- sisteminiai priešgrybeliniai, priešvirusiniai vaistai ir antibiotikai pagal indikacijas;

- H2-blokatoriai (skrandžio, dvylikapirštès žarnos opų profilaktika);

- tromboziu profilaktika;

- psichologiné pagalba.

Ligos kontrolè:

- KS mažinami kas 2 sav. 25 proc., pasiekus ligos kontrolę; 
- atsiradus naujiems bėrimams, grižtama prie paskutinès dozes;

- atkryčio metu KS dozė didinama dviem žingsniais, kol pasiekiama ligos kontrolè. Jos nepasiekus grižtama prie pradinès dozes;

- gydymą KS galima nutraukti, pasiekus visišką ligos remisiją vartojant minimalią prednizolono ar jo ekvivalento $\leq 10 \mathrm{mg} / \mathrm{d}$. dozę;

- adjuvantą nutraukti po 6-12 mèn. [4].

\section{Išvados}

1. Ankstyva autoimuninių pūslinių ligų diagnostika ir savalaikis racionalus gydymas užtikrina greitesnę ligos remisiją ir padeda išvengti gyvybei grèsmingų komplikacijų.

2. Tiesioginè imunofluorescencija - ,auksinis“ autoimuninių pūslinių ligų diagnostikos standartas.

3. Pūslinių ligų gydymas yra sudètingas, pakankamai agresyvus, ilgalaikis ir reikalaujantis iš gydytojo profesinès patirties.

4. Gydymo taktika priklauso nuo ligos patogenetinio mechanizmo, ligos klinikinès išraiškos ir paciento bendros būklès.

5. Sisteminiai kortikosteroidai - bazinè pemfigus terapija.

6. Imunosupresiniai vaistai pridedami tam, kad būtu pasiekta ligos remisija minimaliomis kortikosteroidų dozėmis.

7. Sunkios ligos ir atsparių ịprastinei terapijai pūslinių ligu gydymui kartu su imunosupresantais skiriami biologiniai vaistai, intraveninis imunoglobulinas, imunoadsorbcija.

8. Būtina odos ir gleivinių pažeidimo bei sisteminio gydymo komplikacijų prevencija.

\section{Literatūra}

1. Kneisel A1, Hertl M. Autoimmune bullous skin diseases. Part 2: diagnosis and therapy. J Dtsch Dermatol Ges 2011 Nov;9(11):927-47.

https://doi.org/10.1111/j.1610-0387.2011.07809.x

2. Esmaili N, Mortazavi H, Noormohammadpour P, Boreiri M. Pemphigus Vulgaris and infections: a retrospective study on 155 patients. Autoimmune Diseases Volume 2013 (2013);1-5. https://doi.org/10.1155/2013/834295

3. Santoro AF, Stoopler TE, Werth VP. Pemphigus. Dent Clin North Am 2013 Oct; 57(4).

https://doi.org/10.1016/j.cden.2013.06.002

4. Hertl M1, Jedlickova H, Karpati S, Marinovic B, Uzun S, Yayli S. Pemphigus. S2 Guideline for diagnosis and treatment--guided by the European Dermatology Forum (EDF) in cooperation with the European Academy of Dermatology and Venereology (EADV). J Eur Acad Dermatol Venereol 2015 Mar;29(3):405-14.

https://doi.org/10.1111/jdv.12772
5. Amagai M, Takanawa A, Shimizu T, Hashimoto T. Japanese guidelines for the management of pemphigus. J Dermatol 2014 Jun;41(6):471-86. https://doi.org/10.1111/1346-8138.12486

6. Kneisel A1, Hertl M. Autoimmune bullous skin diseases. Part 1: Clinical manifestations. J Dtsch Dermatol Ges 2011 Oct;9(10):844-56; https://doi.org/10.1111/j.1610-0387.2011.07793.x

7. http://www.medymology.com/search.php?root=Pemphix (2017 m. gegužès 1 d.).

8. Sauvages F, Boissier de. Nosologia methodica sistens morborum classes juxta Sydenhami mentem et botanicum ordinem; vol 1. Amsterdam: de Tournes 1768;430.

9. K Holubar. Etymology of pemphigus. J Am Acad Dermatol 1988;21:155-156 1988;18:1219-1238.

10. Ruocco V, Ruocco E, Lo Schiavo A, Brunetti G, Guerrera LP, Wolf R. Pemphigus: etiology, pathogenesis and inducing or triggering factors: facts and controversies. Clin Dermatol 2013 Jul-Aug;31(4):374-81.

https://doi.org/10.1016/j.clindermatol.2013.01.004

11. Amagai M. Autoimmune and infectious skin diseases that target desmogleins. Proc Jpn Acad Ser B Phys Biol Sci 2010;86(5):524-37.

https://doi.org/10.2183/pjab.86.524

12. Amagai M1, Stanley JR. Desmoglein as a target in skin disease and beyond. J Invest Dermatol 2012 Mar;132(3 Pt 2):776-84. doi: 10.1038/jid.2011.390.

https://doi.org/10.1038/jid.2011.390

13. Kershenovich R, Hodak E, Mimouni D. Diagnosis and classification of pemphigus and bullous pemphigoid. Autoimmun Rev 2014 Apr-May;13(4-5):477-81.

https://doi.org/10.1016/j.autrev.2014.01.011

14. Otten JV. et al. Molecular diagnosis in autoimmune skin blistering conditions. Current Molecular Medicine 2014; 14: 69-95. https://doi.org/10.2174/15665240113136660079

15. Benjamin S. Daniel 1,2 and Dedee F. Murrell. Management of pemphigus. F1000Prime Rep 2014; 6: 32.

16. Cheethman TC, Marcy SM, Tseng HF, Sy LS, Bixler Felicia. et al. Risk of Herpes Zoster and disseminated Varicella Zoster in patients taking immunosuppressant drugs at the time of Zoster vaccination. Mayo Clin Proc 2015 Jul;90(7):865-73.

https://doi.org/10.1016/j.mayocp.2015.04.021

17. EL-Komy MH, Samir N, Shaker OG. Estimation of vitamin D levels in patients with pemphigus vulgaris. J Eur Acad Dermatol Venereol 2014 Jul;28(7):859-63.

https://doi.org/10.1111/jdv.12179

18. Baum S, Sakka N, Artsi O, Trau H, Barzilai A. Diagnosis and classification of of autoimmune blistering diseases. Autoimmun Rev 2014 Apr-May;13(4-5):482-9.

https://doi.org/10.1016/j.autrev.2014.01.047 
19. Leger S, Picard D, Ingen-Housz-Oro S. et al. Prognostic factors of paraneoplastic pemphigus. Arch Dermatol. 2012;148(10):1165-1172.

https://doi.org/10.1001/archdermatol.2012.1830

20. Porro AM. et al. Non-classical forms of pemphigus: pemphigus herpetiformis, IgA pemphigus, paraneoplastic pemphigus and IgG/IgA pemphigus. An Bras Dermatol 2014;89(1):96-117. https://doi.org/10.1590/abd1806-4841.20142459

21. Yung-Tsu Cho, Fang-Yu Lee, Chia-Yu Chu and Li-Fang Wang. First-line combination therapy with rituximab and corticosteroids is effective and safe for pemphigus. Acta Derm Venereol 2014; 94: 472-473

https://doi.org/10.2340/00015555-1746

\section{PEMPHIGUS DIAGNOSIS AND TREATMENT \\ CURRENT ISSUES}

J. Kantauskaitė, J. Ūselienė, I. Marčiukaitienė, J. Grigaitienė

Key words: pemphigus, desmoglein, autoantibodies, immunoflourescence, desmocollin, desmoplakin, envoplakin, periplakin, plectin, skin punch biopsy, systemic immunosuppressants, plasmapheresis, immunoadsorption, rituximab, intravenous immunoglobulin.

Summary

Pemphigus is a heterogeneous autoimmune mucocutaneous disease associated with the production of IgG and IgA autoantibodies against different adhesion molecules in the epidermis and manifesting intraepidermal blisters, which are very fragile, break down quickly, leaving erosions. Pemphigus is classified into several no- soligical units that differ in pathogenesis, autoantibodies binding locations, rash nature and localization. 70 percent of pemphigus vulgaris cases starts with the erosions of the mucous membranes, especially oral. Such painful erosions are found in the skin as well. Pemphigus foliaceus usually affects only the skin, characterized by erosion covered with a puff pastry-like scale. Paraneoplastic pemphigus is a mucocutaneous variant of the paraneoplastic autoimmune multiorgan syndrome with very heterogeneous clinical symptoms. Drug-induced pemphigus is cured by excluding medications which have trigered it. The diagnosis is based on the medical history, clinical examination, laboratory tests. Of these, the most important is direct immunofluorescence, which is the world's "gold standard" for pemphigus accurate diagnosis. Pemphigus treatment is a complex and long-term, depending on the pathogenetic mechanisms and clinical expression of the disease, so the pre-treatment plan requires a careful assessment of the patient's condition. Bullous damage and functional disorders associated with the disease, treatment, recurrence control, the most common side effects associated with long-term treatment with corticosteroids and immunosuppressants reduction, patient's quality of life are the main objectives when this disease is diagnosed. The drugs of first choice in the treatment of pemphigus so far remains a systemic corticosteroids, which combining with adjuvants, can resolve in clinical remission with lowest doses of corticosteroids.

Correspondence to: juste_kantauskaite@yahoo.com

Gauta 2017-10-13 